\title{
STRATEGIES THAT FAVOR MYCORRHIZATION IN THE REFORESTATION OF A DISTURBED AREA IN THE SEMIARID REGION
}

\author{
Mirian Cristina Gomes Costa ${ }^{1 *}$, Mário Rógeson de Abreu Vasconcelos ${ }^{1}$, Roberto Albuquerque Pontes Filho \\ Luan Alves Lima ${ }^{1}$, José Lucas Martins Melo ${ }^{1}$, Paulo Furtado Mendes Filho ${ }^{1}$ \\ 1*Universidade Federal do Ceará, Departamento de Ciências do Solo, Fortaleza, Ceará, Brasil - mirian.costa@ufc.br \\ ${ }^{2}$ Instituto Federal do Ceará, Laboratório da Terra, Maracanaú, Ceará, Brasil \\ Received for publication: 27/03/2020 - Accepted for publications: 30/12/2020
}

\begin{abstract}
Resumo
Estratégias que favorecem a micorrização em reflorestamento de área perturbada no semiárido. Hidrogel e cobertura morta adicionados ao solo podem favorecer fungos micorrízicos arbusculares (FMA), contribuindo com a revegetação de áreas perturbadas no semiárido. Neste estudo de campo o objetivo foi avaliar a colonização por FMA nas raízes de Enterolobium contortisilliquum (Vell.) Morong mediante aplicação de hidrogel e bagana de carnaúba (Copernica cerifera L.) ao solo, bem como seus efeitos no solo e na planta. Em abril de 2014 um experimento foi instalado em Ibaretama (Ceará, Brasil), com delineamento em blocos aleatorizados, em esquema fatorial $2 \times 4$ - com bagana (+M) e sem bagana (-M) x doses de hidrogel $(0,4,5$ e 6 $\mathrm{g} \mathrm{L}^{-1}$ ) - com cinco repetições. Aos 18 meses após instalação do experimento foram coletadas amostras de raízes, solo e folhas para análises da colonização por FMA nas raízes e dos teores de nutrientes no solo e no tecido vegetal. A dose $6 \mathrm{~g} \mathrm{~L}^{-1}$ de hidrogel e a aplicação do equivalente a $10 \mathrm{Mg} \mathrm{ha}^{-1}$ de bagana de carnaúba aumentaram a colonização de raízes por FMA em 21 e 44\%, respectivamente. Os teores de Ca, $\mathrm{K}$ e Zn no solo diminuíram com as doses de hidrogel na ausência de bagana, mas aumentaram na presença do resíduo aplicado como cobertura morta. Não foi observado maior teor foliar de P associado com a colonização por FMA. O teor foliar de Ca respondeu apenas ao tratamento com bagana, atingindo maior valor $\left(3,8 \mathrm{~g} \mathrm{~kg}^{-1}\right)$ na ausência da cobertura morta.
\end{abstract}

Palavras-chave: Tamboril; Polímero superabsorvente; Cobertura de solo; Recuperação do solo, Micorrizas

\section{Abstract}

Hydrogel and mulch added to the soil may favor arbuscular mycorrhizal fungi (AMF), contributing to the reforestation of disturbed lands in semiarid regions. This study aimed to evaluate AMF colonization in the roots of Enterolobium contortisiliquum (Vell.) Morong in response to the application of hydrogel and mulch (bagana) from carnauba palm (Copernicia cerifera L.) to the soil and their effects in the soil and plants. A field experiment was set up in April 2014 in Ibaretama (Ceará, Brazil) in a randomized block design in a $2 \times 4$ factorial scheme - with mulch $(+\mathrm{M})$ e without mulch $(-\mathrm{M}) \times$ hydrogel doses $\left(0,4,5\right.$, and $\left.6 \mathrm{~g} \mathrm{~L}^{-1}\right)-$, with five replicates. Samples of roots, soil, and leaves were collected 18 months after the beginning of the experiment to determine AMF colonization in the roots and nutrient contents in the soil and plant material. The hydrogel dose of $6 \mathrm{~g} \mathrm{~L}^{-1}$ and mulch application equivalent to $10 \mathrm{Mg} \mathrm{ha}^{-1}$ increased AMF colonization by $21 \mathrm{e} 44 \%$, respectively. Soil contents of $\mathrm{Ca}, \mathrm{K}$, and $\mathrm{Zn}$ decreased with hydrogel doses without mulch but increased in the presence of the carnauba palm residue applied as mulch. A higher P content in the plant material was not associated with AMF colonization. The leaf content of Ca responded only to the treatment with mulch, reaching the highest value $\left(3.8 \mathrm{~g} \mathrm{~kg}^{-1}\right)$ in the absence of mulch.

Keywords: Pacara earpod tree; Superabsorbent polymer; Soil cover; Soil rehabilitation, Mycorrhizae

\section{INTRODUCTION}

Global climate change has raised concerns about the expansion of semiarid regions and increased negative impacts caused by the water deficit. Land disturbance and degradation in the Brazilian semiarid region are another concern, as the recovery of these areas requires reforestation actions in which the species Enterolobium contortisiliquum (Vell.) Morong (pacara earpod tree) can be used. This deciduous species belongs to the family Fabaceae, has a wide distribution in Brazilian biomes, tuberous roots, and rapid growth (LORENZI, 2009). However, water deficit and low fertility of degraded soils have limited the reforestation in the semiarid region (RODORFF et al., 2018). In this context, the adoption of conservationist practices, such as the use of soil amendments and mulch, and the interaction of plants with microorganisms become important strategies for revegetation.

The hydrogel can be used as a soil amendment, improving water availability to plants (SAHA et al., 2020). It is a superabsorbent polymer consisting of a slightly reticulate, three-dimensional polymeric network generally composed of ionic monomers with swelling capacity in the presence of water (SAHA et al., 2020). Some studies have reported the potential use of this polymer in agriculture and forestry (SAHA et al., 2020; PONTES FILHO et al., 2018).

The use of hydrogels associated with other soil conservation practices, such as the maintenance of mulch

FLORESTA, Curitiba, PR, v. 51, n. 3, p. 741-750, jul/set 2021

Costa, M. C. G. et.al. 
from carnauba palm (Copernicia cerifera L.) bagana, can be even more effective in favoring reforestation in the semiarid region. Bagana residues contribute to the conservation of moisture and release of nutrients in the soil (OLIVEIRA et al., 2018), also favoring the soil biota, including arbuscular mycorrhizal fungi (AMF).

AMF are important for the reforestation of disturbed areas because they contribute to the absorption of nutrients such as phosphorus (MANAUT et al., 2015). Inoculation of E. contortisiliquum with AMF obtained from the rhizosphere of plants of the same host species has increased the leaf content of phosphorus compared to noninoculated plants (ABREU et al., 2018). Different strains of AMF associated with E. contortisiliquum have been found in the Brazilian semiarid (PAGANO et al., 2011).

Mycorrhization has the potential to favor the development of species used in the reforestation of disturbed areas that present mycorrhizal fungus propagules. Some AMF species do not tolerate water deficit (RYDLOVÁ; PÜSCHEL, 2020), and the higher water retention in the soil promoted by the addition of hydrogel may favor mycorrhization. The residue from carnauba palm used as mulch (bagana) may influence mycorrhizal colonization through a higher soil water retention. However, there is a report that AMF development in tuberous roots, such as that of E. contortisiliquum, depends on the composition of the organic residue used as mulch (KOLAWOLE, 2012).

This study hypothesized that AMF colonization in the roots of E. contortisiliquum is favored by the application of hydrogel doses and carnauba palm bagana as mulch in a soil reforestation strategy in disturbed areas of the Brazilian semiarid region, favoring mineral nutrition of plants. In this sense, this study aimed to evaluate AMF colonization in the roots of E. contortisiliquum and the content of nutrients in the soil and plant material in response to treatments with and without carnauba palm bagana and hydrogel doses.

\section{MATERIAL AND METHODS}

\section{Characterization of the experimental area}

The study was carried out on the Triunfo farm (Ibaretama, CE, Brazil) (Figure 1). The climate classification of the region, according to the Köppen-Geiger (1918) classification, is BShw', that is, semi-arid hot tropical climate, with an average annual temperature of $27{ }^{\circ} \mathrm{C}$ and average annual precipitation of $838.1 \mathrm{~mm}$ between January and April (IPECE, 2017).

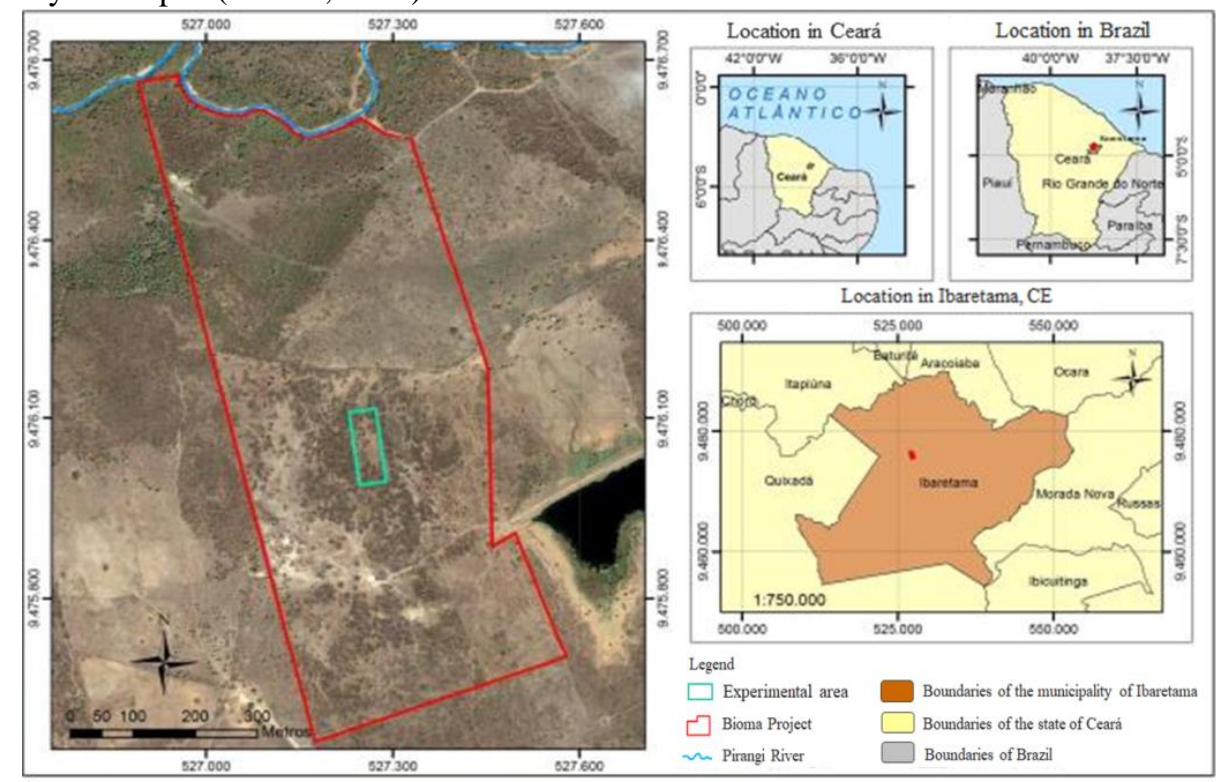

Figure 1. Experimental site on the Triunfo farm (Ibaretama, CE).

Figura 1. Área experimental na fazenda Triunfo (Ibaretama, CE).

The site where the study was carried out was defined as a disturbed area, whose history of use is related to timber extraction and by-products of the carnauba palm, in addition to extensive farming with successive use of fire (GONÇALVES et al., 2019).

The soil of the experimental area was classified as a PLANOSSOLO HÁPLICO Eutrófico solódico (Brazilian Soil Classification System), with a sandy to medium texture. The soil chemical and particle size attributes in the experimental area are shown in Table 1, according to Pontes Filho et al. (2018). The contents of exchangeable bases $\left(\mathrm{Ca}^{2+}, \mathrm{Mg}^{2+}\right.$, and $\left.\mathrm{K}^{+}\right)$, cation exchange capacity (CEC), phosphorus (P), pH, and soil organic matter (SOM) were classified as low and the content of aluminum (Al) was classified as medium according to the 
criteria presented in Sobral et al. (2015), confirming the chemical degradation of the soil.

Table 1. Chemical attributes, particle size distribution, and textural class of the soil used in the experiment carried out in Ibaretama, Ceará, Brazil.

Tabela 1. Atributos químicos, distribuição do tamanho de partícula e classe textural do solo utilizado no experimento em Ibaretama, Ceará.

\begin{tabular}{|c|c|c|c|c|c|c|c|c|c|c|}
\hline $\mathrm{pH}$ & $\mathrm{Ca}^{2+}$ & $\mathrm{Mg}^{2+}$ & $\mathrm{K}^{+}$ & $\mathrm{Na}^{+}$ & $\mathrm{H}^{+}+\mathrm{Al}^{3+}$ & $\mathrm{Al}^{3+}$ & SB & $\mathrm{CEC}$ & $\mathrm{V}$ & $\mathrm{P}$ \\
\hline (water) & \multicolumn{8}{|c|}{ 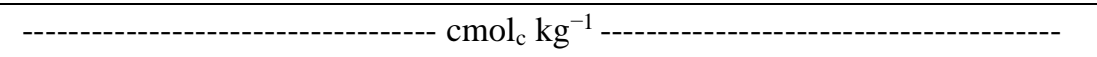 } & $\%$ & $\mathrm{mg} \mathrm{kg}^{-1}$ \\
\hline 4.9 & 0.50 & 0.30 & 0.14 & 0.07 & 1.98 & 0.85 & 1.01 & 3.00 & 33.80 & 2.0 \\
\hline SOM & \multicolumn{8}{|c|}{ Particle size distribution $\left(\mathrm{g} \mathrm{kg}^{-1}\right)$} & \multirow{2}{*}{\multicolumn{2}{|c|}{ Textural class }} \\
\hline $\mathrm{g} \mathrm{kg}^{-1}$ & & Sand & & Silt & & & Clay & & & \\
\hline 6.02 & & 835.0 & & 66.8 & & & 98.2 & & \multicolumn{2}{|c|}{ Sandy } \\
\hline $\begin{array}{l}\mathrm{Ca}^{2+}=\text { calci } \\
\text { xchange ca } \\
\mathrm{K}^{+} \text {and P ex } \\
\text { carbon mult } \\
\text { vith dichror }\end{array}$ & $\mathrm{Mg}^{2+}=$ & gnesium & $+=$ pota & um, $\mathrm{H}^{+}$ & drogen, $\mathrm{Al}^{3+}$ & luminu & $=$ phosp & $\mathrm{s}, \mathrm{SB}=$ & $\mathrm{n}$ of base & $\mathrm{CEC}=\mathrm{cat}$ \\
\hline
\end{tabular}

\section{Design and experiment set up}

The experiment was set up in April 2014 in a randomized block design in a $2 \times 4$ factorial scheme, with five replications, totaling 40 experimental units. Each experimental unit consisted of four planting rows of the species Enterolobium contortisiliquum (Vell.) Morong (IPA 39501) (pacara earpod tree), with a $2 \times 3 \mathrm{~m}$ spacing and two rows in the center of each plot as the useful area, with three plants each row. The first factor consisted of the use of mulch (with and without carnauba palm bagana), while the second factor consisted of four hydrogel doses $\left(0,4,5\right.$, and $\left.6 \mathrm{~g} \mathrm{~L}^{-1}\right)$.

Seedlings of E. contortisiliquum were produced in Styrofoam trays with a substrate based on sand and organic compost $(1: 1 \mathrm{v} / \mathrm{v})$. The seedlings were transferred to polyethylene bags $(12 \times 26 \mathrm{~cm})$ filled with substrate consisting of $70 \%$ sand and $30 \%$ organic compost at 15 days after sowing, where they remained until reaching a mean height of $35 \mathrm{~cm}$.

A commercial potassium acrylate-based polymer (PONTES FILHO et al., 2018) was used. Dry granules of this polymer were diluted in $1 \mathrm{~L}$ of water, according to the doses of each treatment $\left(4,5\right.$, and $\left.6 \mathrm{~g} \mathrm{~L}^{-1}\right)$ and applied to the respective pits $(20 \times 20 \times 20 \mathrm{~cm})$. A total of $1 \mathrm{~L}$ of water was applied to each pit of the treatments that did not receive hydrogel. A layer of soil from the opening of the pits was added over the polymer contained inside the pits to avoid direct contact of the seedling roots with the hydrogel. The seedlings were planted in the pits filled with the remaining soil.

Mulch treatments consisted of the presence $(+\mathrm{M})$ and absence $(-\mathrm{M})$ of carnauba palm bagana (Copernicia cerifera L.). Table 2 shows the chemical characterization of carnauba palm bagana. An amount of bagana corresponding to $10 \mathrm{Mg} \mathrm{ha}^{-1}$ was applied on the soil surface around each plant. A $5-\mathrm{mm}$ mesh $(0.80 \times 0.80 \mathrm{~m})$ plastic screen was installed and fixed on the surface occupied by the bagana to avoid its removal by the wind.

Table 2. Chemical characterization of carnauba palm bagana (Copernicia cerifera L.) used as mulch in the experiment carried out in Ibaretama, Ceará, Brazil.

Tabela 2. Caracterização química da bagana de carnaúba (Copernica cerifera L.) utilizada como cobertura morta no experimento em Ibaretama, Ceará

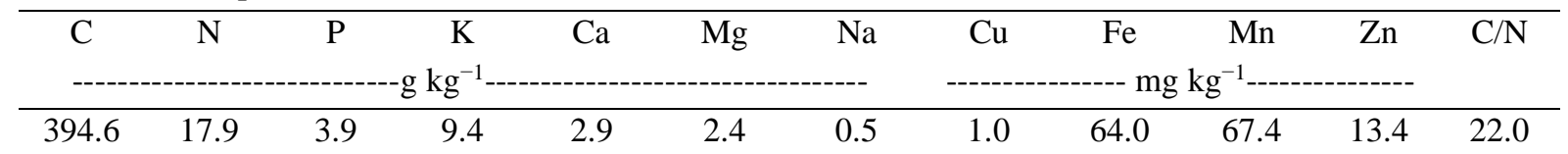

$\overline{\mathrm{C}}=$ carbon, digestion with potassium dichromate followed by titration with ferrous ammonium sulfate; $\mathrm{N}=$ nitrogen, sulfuric digestion followed by the semi-micro Kjeldahl method; $\mathrm{P}=$ phosphorus, nitric-perchloric digestion followed by spectrometry with vanadate yellow; $\mathrm{K}$ = potassium and $\mathrm{Na}=$ sodium, nitric-perchloric digestion followed by flame emission spectrometry; $\mathrm{Ca}=\mathrm{calcium}, \mathrm{Mg}=\mathrm{magnesium}, \mathrm{Cu}=$ copper, $\mathrm{Fe}=$ iron, $\mathrm{Mn}=$ manganese, and $\mathrm{Zn}=$ zinc, nitric-perchloric digestion followed by atomic absorption spectrometry; $\mathrm{C} / \mathrm{N}=$ carbon to nitrogen ratio.

\section{Sampling and evaluations}

Soil and plant material samples were collected in October 2015 (18 months after the experiment set up). Disturbed soil samples were collected at a depth of 0-20 cm through mini trenches $(0.20 \times 0.20 \times 0.20 \mathrm{~m})$ opened next to three plants per plot. The collection was carried out in duplicate to enable the analysis of mycorrhizal fungi and nutrient availability in the soil.

The soil samples were refrigerated soon after collection to avoid dehydration of the root fragments and

FLORESTA, Curitiba, PR, v. 51, n. 3, p. 741-750, jul/set 2021. 
the decrease in quality of the material for analysis of AMF colonization. Thinner root fragments contained in the soil samples were selected by applying the root staining methodology proposed by Koske and Gemma (1989). The percentage of root colonization by arbuscular mycorrhizal fungi was determined by the method described by McGonigle et al. (1990), which consists of observing each of the 10 fragments per slide under an optical microscope $(40 \mathrm{x})$ and assigning a percentage of colonization.

The samples destined to soil chemical analysis were dried under shading, decloded, and passed through a 2-mm mesh sieve. Phosphorus (P), potassium (K), sodium (Na), and micronutrients were extracted by Mehlich1 , with determinations made by colorimetry $(\mathrm{P})$, flame emission spectrometry ( $\mathrm{K}$ and $\mathrm{Na}$ ), and atomic absorption spectrometry (Cu, Fe, Mn, and $\mathrm{Zn}$ ), according to the methods described by Teixeira et al. (2017). Calcium (Ca) and magnesium $(\mathrm{Mg})$ were extracted by ammonium acetate solution and determined by atomic absorption spectrometry.

Fully expanded leaves were collected from three E. contortisiliquum plants grown in the useful area of the plots, that is, from the same sites where the soil samples were collected. The collected leaves were not senescent and had the petioles removed. After collection, the sampled leaves were placed in properly identified paper bags and taken to a forced-air circulation oven at $65^{\circ} \mathrm{C}$ until reaching constant weight. Then, the material was milled and passed through 1.0-mm mesh sieves.

The nutritional status of pacara earpod tree plants was evaluated after extracting $\mathrm{P}, \mathrm{K}, \mathrm{Na}, \mathrm{Ca}, \mathrm{Mg}$, and micronutrients $(\mathrm{Cu}, \mathrm{Fe}, \mathrm{Mn}$, and $\mathrm{Zn})$ by nitric-perchloric digestion, with determinations of $\mathrm{P}$ by spectrometry with vanadate yellow, $\mathrm{K}$ and $\mathrm{Na}$ by flame emission spectrometry, and $\mathrm{Ca}, \mathrm{Mg}$, and micronutrients by atomic absorption spectrometry (TEIXEIRA et al., 2017).

\section{Statistical analyses}

The data were subjected to analysis of variance by the F-test when normal distribution was verified, with the slicing of the variables that showed a significant response to the interaction between the studied factors. The effect of mulch was evaluated by applying the Tukey test $(\mathrm{p}<0.05)$ and the effects of hydrogel doses by regression analysis using the software Sisvar v. 5.6.

\section{RESULTS}

\section{Mycorrhization}

Colonization by arbuscular mycorrhizal fungi (AMF) in the roots of E. contortisiliquum was responsive to hydrogel doses $(\mathrm{P}<0.01)$ and mulch with carnauba palm bagana $(\mathrm{P}<0.01)$ alone (Table 3$)$.

Table 3. Summary of analysis of variance for mycorrhization (AMF) and contents of macronutrients (P, Ca, Mg, and $\mathrm{K})$, sodium $(\mathrm{Na})$, and micronutrients $(\mathrm{Cu}, \mathrm{Fe}, \mathrm{Mn}$, and $\mathrm{Zn})$ in the soil as a function of hydrogel doses (HD) and mulch (M).

Tabela 3. Resumo da ANOVA para micorrização (AMF) e teores de macronutrientes (P, Ca, Mg, K), sódio (Na) e micronutrientes $(\mathrm{Cu}, \mathrm{Fe}, \mathrm{Mn}, \mathrm{Zn})$ no solo em função de doses de hidrogel (HD) e cobertura morta (M).

\begin{tabular}{|c|c|c|c|c|c|c|c|c|c|c|}
\hline $\mathrm{SV}^{1}$ & AMF & $\mathrm{P}$ & $\mathrm{K}$ & $\mathrm{Ca}$ & $\mathrm{Mg}$ & $\mathrm{Na}$ & $\mathrm{Cu}$ & $\mathrm{Fe}$ & $\mathrm{Mn}$ & $\mathrm{Zn}$ \\
\hline HD & $3.95^{*}$ & $2.76^{\mathrm{ns}}$ & $0.49^{\mathrm{ns}}$ & $0.98^{\mathrm{ns}}$ & $0.45^{\mathrm{ns}}$ & $0.85^{\mathrm{ns}}$ & $2.04^{\mathrm{ns}}$ & $2.48^{\mathrm{ns}}$ & $2.15^{\mathrm{ns}}$ & $1.73^{\mathrm{ns}}$ \\
\hline M & $65.23^{* * *}$ & $0.95^{\mathrm{ns}}$ & $21.86^{*}$ & $2.68^{\mathrm{ns}}$ & $0.00^{\mathrm{ns}}$ & $0.42^{\mathrm{ns}}$ & $1.34^{\mathrm{ns}}$ & $0.59^{\mathrm{ns}}$ & $0.48^{\text {ns }}$ & $4.28^{*}$ \\
\hline $\mathrm{HD} \times \mathrm{M}$ & $0.54^{\mathrm{ns}}$ & $0.60^{\mathrm{ns}}$ & $3.12^{*}$ & $3.07^{*}$ & $1.70^{\mathrm{ns}}$ & $1.17^{\mathrm{ns}}$ & $0.87^{\mathrm{ns}}$ & $1.13^{\mathrm{ns}}$ & $2.18^{\mathrm{ns}}$ & $3.93^{*}$ \\
\hline $\mathrm{CV}^{2}(\%)$ & 22.0 & 46.3 & 29.8 & 35.3 & 19.7 & 4.9 & 11.6 & 26.8 & 25.3 & 38.0 \\
\hline
\end{tabular}

${ }^{1} \mathrm{SV}$ source of variation; ${ }^{\mathrm{ns}}$ not significant; $* *$ and $*$ significant at 1 and $5 \%$ of probability, respectively; ${ }^{2} \mathrm{CV}$ coefficient of variation.

The treatment with mulch $(+\mathrm{M})$ resulted in higher colonization $(54.4 \%)$ than that found in the treatment without mulch $(-\mathrm{M})(30.6 \%)$, representing a $44 \%$ increase in colonization (Figure 2A). The response to hydrogel doses was quadratic with a minimum point so that the $40 \%$ colonization observed at zero hydrogel dose decreased to $33 \%$ at the $2.4 \mathrm{~g} \mathrm{~L}^{-1}$ dose (Figure $2 \mathrm{~B}$ ). An increase in AMF colonization was observed from the $2.4 \mathrm{~g} \mathrm{~L}^{-1} \mathrm{dose}$, reaching a maximum value of $50.6 \%$ at the polymer dose of $6 \mathrm{~g} \mathrm{~L}^{-1}$ (Figure 2B). The highest hydrogel dose increased AMF colonization by $21 \%$ compared to its non-application (Figure $2 \mathrm{~B}$ ). 

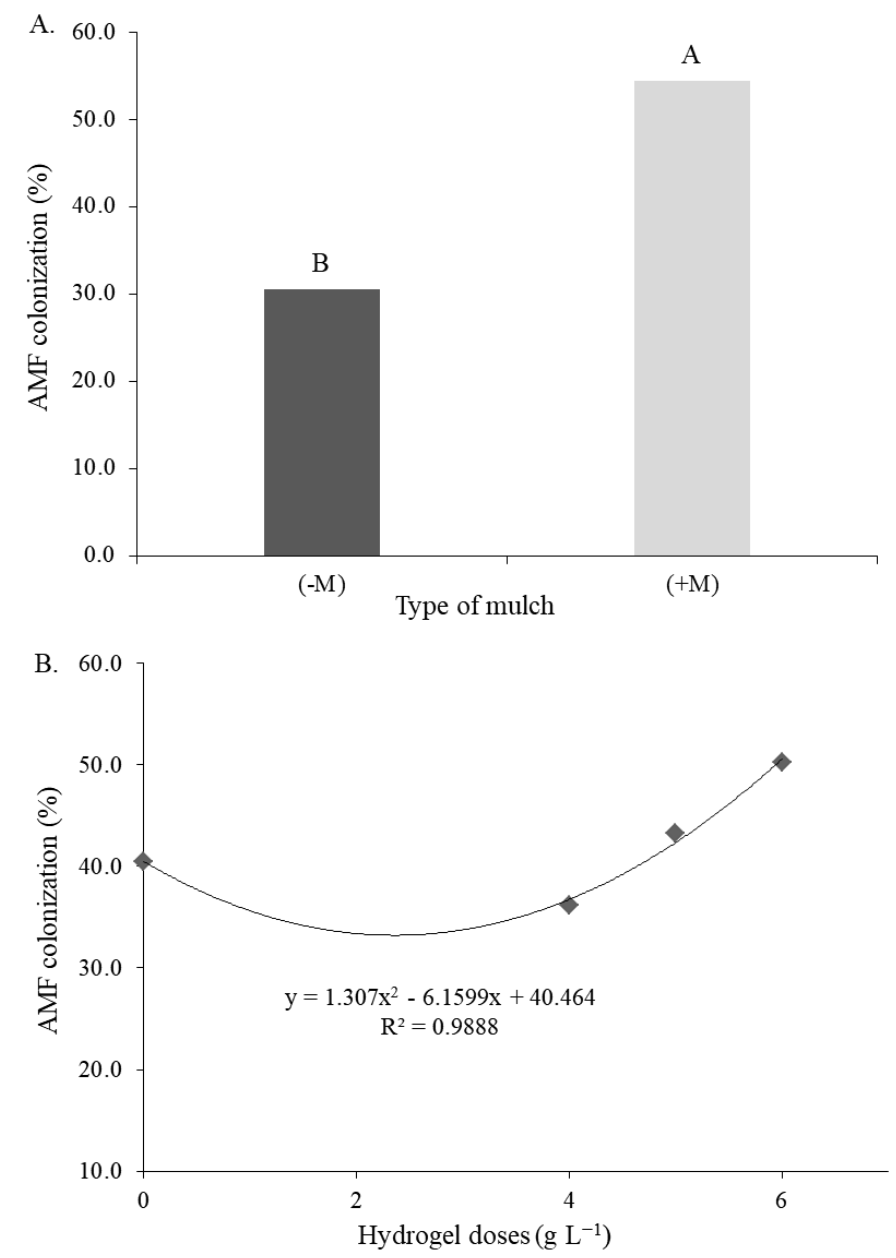

Figure 2. Colonization of E. contortisiliquum roots by arbuscular mycorrhizal fungi (AMF) in response to treatments with $(+\mathrm{M})$ and without mulch $(-\mathrm{M})$ from carnauba palm bagana $(\mathrm{A})$ and hydrogel doses $(\mathrm{B})$.

Figura 2. Colonização das raízes de E. contortisilliquum por fungos micorrízicos arbusculares (FMA) em resposta aos tratamentos com $(+\mathrm{M})$ e sem cobertura $(-\mathrm{M})$ com bagana de carnaúba $(\mathrm{A})$ e às doses de hidrogel (B).

\section{Soil nutrient contents}

A significant interaction $(\mathrm{P}<0.05)$ was observed between treatments for calcium $(\mathrm{Ca})$, potassium $(\mathrm{K})$, and zinc $(\mathrm{Zn})$ contents in the soil (Table 3$)$. In the absence of mulch $(-\mathrm{M})$, the Ca content in the soil was higher $(1.5$ $\mathrm{cmol}_{\mathrm{c}} \mathrm{kg}^{-1}$ ) at zero hydrogel dose but decreased with doses reaching the minimum value of $1.01 \mathrm{cmol}_{\mathrm{c}} \mathrm{kg}^{-1}$ (Figure $3 \mathrm{~A})$. In the presence of mulch $(+\mathrm{M})$, the initial Ca contents in the soil were lower at zero hydrogel dose $\left(0.76 \mathrm{cmol}_{\mathrm{c}}\right.$ $\mathrm{kg}^{-1}$ ) and increased with the doses. Thus, the $\mathrm{Ca}$ contents obtained in the $+\mathrm{M}$ treatment exceeded the contents of the $-\mathrm{M}$ treatment from the hydrogel dose of $5 \mathrm{~g} \mathrm{~L}^{-1}$, reaching a maximum value of $1.17 \mathrm{cmol}_{\mathrm{c}} \mathrm{kg}^{-1}$ (Figure $3 \mathrm{~A}$ ).

The same trend observed for $\mathrm{Ca}$ occurred for $\mathrm{K}$, as the absence of mulch $(-\mathrm{M})$ reduced $\mathrm{K}$ contents from $0.25 \mathrm{cmol}_{\mathrm{c}} \mathrm{kg}^{-1}$ at the zero dose to $0.15 \mathrm{cmol}_{\mathrm{c}} \mathrm{kg}^{-1}$ at the maximum polymer dose $\left(6 \mathrm{~g} \mathrm{~L}^{-1}\right)$ (Figure $\left.3 \mathrm{~B}\right)$. On the other hand, the $\mathrm{K}$ content in the soil in the presence of mulch $(+\mathrm{M})$ increased from $0.27 \mathrm{cmol}_{\mathrm{c}} \mathrm{kg}^{-1}$ to 0.31 and $0.35 \mathrm{cmol}_{\mathrm{c}} \mathrm{kg}^{-1}$ for hydrogel doses of 5 and $6 \mathrm{~g} \mathrm{~L}^{-1}$, respectively (Figure 3B). The application of $6 \mathrm{~g} \mathrm{~L}^{-1}$ of hydrogel associated with mulch resulted in a $133 \%$ increase in the potassium content in the soil (Figure 3B).

The $\mathrm{Zn}$ content in the soil without mulch addition (-M) was higher $\left(3.5 \mathrm{mg} \mathrm{kg}^{-1}\right)$ at zero hydrogel dose and decreased to $1.67 \mathrm{mg} \mathrm{kg}^{-1}$ at the highest polymer dose $\left(6 \mathrm{~g} \mathrm{~L}^{-1}\right)$ (Figure 3C). On the contrary, the $\mathrm{Zn}$ content in the soil in the presence of mulch $(+\mathrm{M})$ was lower at zero hydrogel dose $\left(1.60 \mathrm{mg} \mathrm{kg}^{-1}\right)$ but increased from the polymer dose of $4 \mathrm{~g} \mathrm{~L}^{-1}$ until reaching a value of $2.24 \mathrm{mg} \mathrm{kg}^{-1}$ (Figure 3C). 


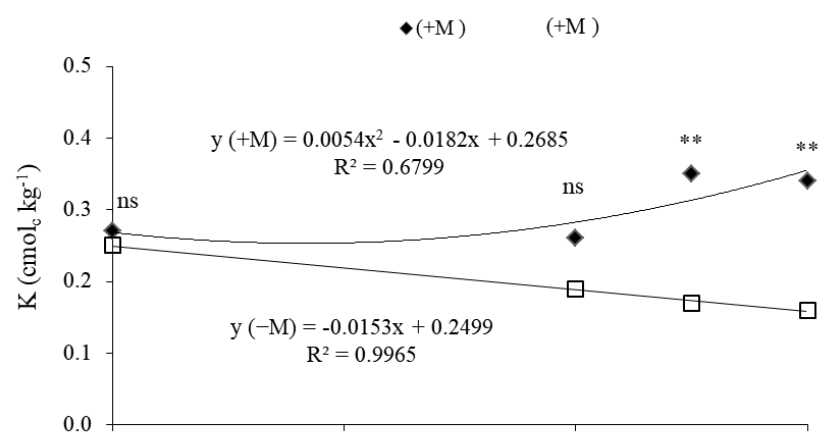

B.

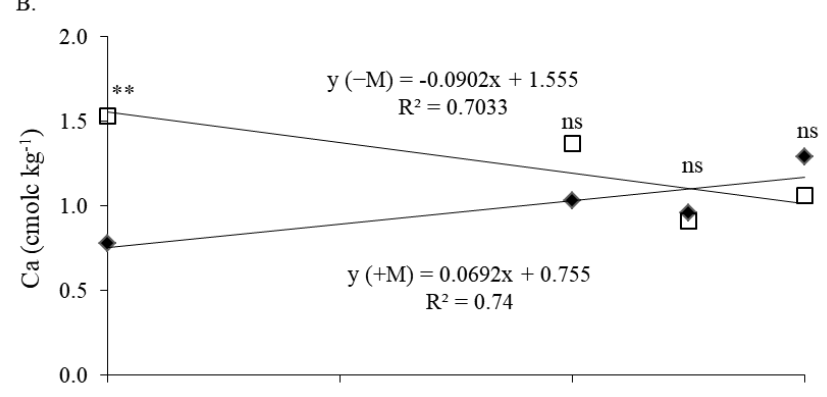

C

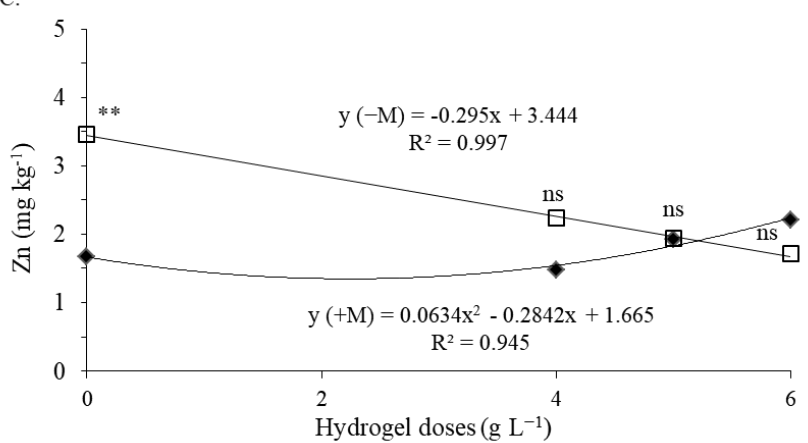

Figure 3. Contents of calcium (A), potassium (B), and zinc (C) in the soil in response to treatments with $(+\mathrm{M})$ and without mulch $(-\mathrm{M})$ from carnauba palm bagana and hydrogel doses.

Figura 3. Teores de cálcio (A), potássio (B) e zinco (C) no solo em resposta aos tratamentos com (+M) e sem cobertura (-M) de bagana de carnaúba e doses de hidrogel.

\section{Nutrient content in the plant material}

The analysis of the plant tissue of $E$. contortisiliquum showed differences for the $\mathrm{Ca}(\mathrm{P}<0.05)$ and $\mathrm{Mg}$ $(\mathrm{P}<0.01)$ contents in response to mulch with carnauba palm bagana (Table 4).

Table 4. Summary of analysis of variance for contents of macronutrients (N, P, K, Ca, and $\mathrm{Mg}$ ), sodium (Na), and micronutrients $(\mathrm{Cu}, \mathrm{Fe}, \mathrm{Mn}$, and $\mathrm{Zn})$ in the plant tissue of E. contortisiliquum as a function of hydrogel doses (HD) and mulch (M).

Tabela 4. Resumo da ANOVA para teores de macronutrientes (N, P, K, Ca, Mg), sódio ( $\mathrm{Na}$ ) e micronutrientes $(\mathrm{Cu}, \mathrm{Fe}, \mathrm{Mn}, \mathrm{Zn})$ no tecido vegetal do E. contortisilliquum em função de doses de hidrogel (HD) e cobertura morta $(\mathrm{M})$

\begin{tabular}{llccccccccc}
\hline $\mathrm{SV}^{1}$ & $\mathrm{~N}$ & $\mathrm{P}$ & $\mathrm{K}$ & $\mathrm{Ca}$ & $\mathrm{Mg}$ & $\mathrm{Na}$ & $\mathrm{Cu}$ & $\mathrm{Fe}$ & $\mathrm{Mn}$ & $\mathrm{Zn}$ \\
& & $-{ }^{------------------------F-v a l u e s------------------------}$ & \\
\hline $\mathrm{HD}$ & $2.31^{\text {ns }}$ & $2.42^{\text {ns }}$ & $1.56^{\text {ns }}$ & $2.53^{\text {ns }}$ & $1.62^{\text {ns }}$ & $0.98^{\text {ns }}$ & $0.09^{\text {ns }}$ & $2.53^{\text {ns }}$ & $1.24^{\text {ns }}$ & $1.24^{\text {ns }}$ \\
$\mathrm{M}$ & $0.11^{\text {ns }}$ & $1.28^{\text {ns }}$ & $2.07^{\text {ns }}$ & $9.00^{* *}$ & $6.10^{*}$ & $0.08^{\text {ns }}$ & $0.29^{\text {ns }}$ & $0.38^{\text {ns }}$ & $0.00^{\text {ns }}$ & $0.00^{\text {ns }}$ \\
$\mathrm{HD} \times \mathrm{M}$ & $0.71^{\text {ns }}$ & $2.73^{\text {ns }}$ & $0.61^{\text {ns }}$ & $2.1^{\text {ns }}$ & $2.49^{\text {ns }}$ & $0.37^{\text {ns }}$ & $0.92^{\text {ns }}$ & $1.24^{\text {ns }}$ & $0.23^{\text {ns }}$ & $0.15^{\text {ns }}$ \\
$\mathrm{CV}^{2}(\%)$ & 11.2 & 12.7 & 21.2 & 23.6 & 15.6 & 34.3 & 20.2 & 29.7 & 36.9 & 15.7 \\
\hline
\end{tabular}

${ }^{1} \mathrm{SV}$ source of variation; ${ }^{\text {ns }}$ not significant; $* *$ and $*$ significant at 1 and $5 \%$ of probability, respectively; ${ }^{2} \mathrm{CV}$ coefficient of variation. 
The leaf contents of $\mathrm{Ca}$ were higher $\left(3.8 \mathrm{~g} \mathrm{~kg}^{-1}\right)$ in the treatment without mulch $(-\mathrm{M})$ and lower $(3.0 \mathrm{~g}$ $\left.\mathrm{kg}^{-1}\right)$ in the treatment with mulch $(+\mathrm{M})$ (Figure 4A). The highest leaf content of $\mathrm{Mg}\left(6.6 \mathrm{~g} \mathrm{~kg}^{-1}\right)$ was found for the $-\mathrm{M}$ treatment and the lowest content $\left(5.9 \mathrm{~g} \mathrm{~kg}^{-1}\right)$ was observed for the $+\mathrm{M}$ treatment (Figure $\left.4 \mathrm{~B}\right)$.
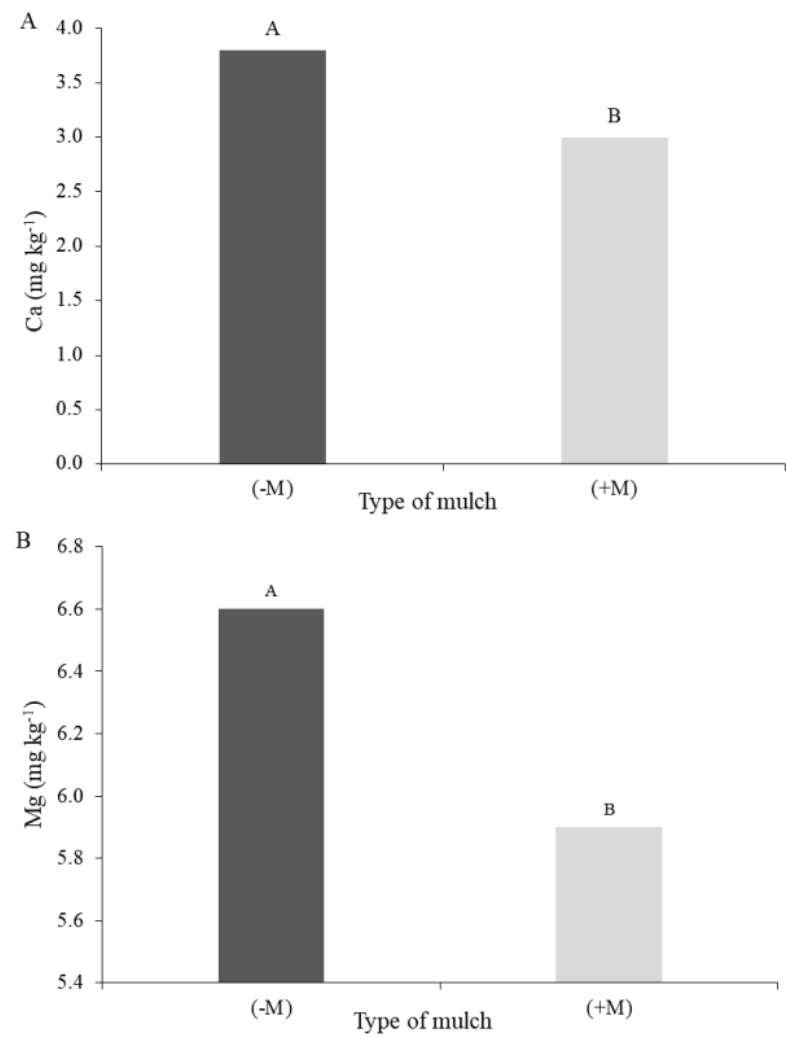

Figure 4. Contents of calcium (A) and magnesium (B) in the leaf tissue of E. contortisiliquum in response to treatments with $(+\mathrm{M})$ and without mulch $(-\mathrm{M})$ from carnauba palm bagana and hydrogel doses.

Figura 4. Conteúdo de cálcio (A) e magnénio (B) no tecido foliar de E. contortisiliquum em resposta aos tratamentos com $(+\mathrm{M})$ e sem cobertura $(-\mathrm{M})$ de bagana de carnauba e doses de hidrogel.

No effect of hydrogel doses was observed on the contents of the elements in the leaf tissue, that is, polymer doses provided no changes in the leaf contents of nutrients (Table 4) despite the significance for nutrients such as calcium, potassium, and zinc in the soil (Table 3 ).

\section{DISCUSSION}

\section{Mycorrhization}

Mycorrhization occurred even without inoculation and was $36 \%$ higher than that found by Abreu et al. (2018) when inoculating E. contortisiliquum with an exotic AMF. It indicates that the soil of the disturbed area has viable native AMF propagules that colonized the host species. The highest AMF colonization through inoculation in Manihot esculenta was explained by the low availability of viable propagules in the soil due to intensive cultivation (OKON et al., 2010). Thus, the higher the disturbance of the environment, bringing the soil closer to degradation, the higher the importance of inoculation for AMF to colonize the host species and contribute to reforestation.

The low phosphorus (P) content available in the studied soil (Table 1) favored AMF colonization, as there is a higher mycorrhization in P-poor soils (NOGUEIRA; CARDOSO, 2007). However, an increase in mycorrhization has already been observed in tuberous roots in response to the increased $\mathrm{P}$ content in the soil (KOLAWOLE, 2012). These differences in mycorrhization as a function of $\mathrm{P}$ content in the soil are explained by the variation that occurs between the existing fungi species and nutrient compartments in the soil (NOGUEIRA; CARDOSO, 2007; KOLAWOLE, 2012).

A higher AMF colonization was observed in the treatment in which mulch $(+\mathrm{M})$ was applied. It occurred because the organic material conserves moisture and is a source of nutrients for microorganisms, making the environment conducive to the development of mycorrhizal fungi (POWELL; RILLIG, 2018). The influence of 
moisture on mycorrhization will be discussed together with the response to hydrogel doses. Regarding the influence of nutrients in the used mulch, AMF have a high demand for nitrogen $(\mathrm{N})$, which is obtained from organic materials (HODGE; FITTER, 2010).

However, Kolawole (2012) found no AMF response to the application of Pueraria residues in the soil, but residues from the soybean crop showed a response. According to the author, it occurred due to differences in the composition of the applied residues, which includes the $\mathrm{C} / \mathrm{N}$ ratio. The AMF Glomus hoi was favored when acquiring $\mathrm{N}$ resulting from the decomposition of organic residue, whose $\mathrm{C} / \mathrm{N}$ ratio was 19:1 (HODGE; FITTER, 2010). In the present study, the carnauba palm bagana presented a $\mathrm{C} / \mathrm{N}$ ratio equal to 22 (Table 2), which, together with other factors, results in high $\mathrm{N}$ mineralization, contributing to mycorrhization.

Similar to that observed for the carnauba palm bagana, the application of hydrogel doses was also considered beneficial to the increase in mycorrhization because it contributes to the higher conservation of moisture in the soil. A positive correlation was observed between soil moisture and the presence of AMF external hyphae (POSADA et al., 2007). The soil in the area under study has a sandy texture (Table 1) and, consequently, a low water retention capacity. The use of hydrogel in sandy soils can increase the moisture in the field capacity several times, favoring the development of plants and microorganisms (SAHA et al., 2020). The conservation and increase in soil moisture promoted by the application of bagana and hydrogel are desirable in semiarid regions, as local edaphoclimatic conditions compromise water availability and, consequently, the potential for reforestation of disturbed areas.

A study showed that water deficit can increase AMF colonization, but it is not a general and uniform trend, as mycorrhization can decrease when water deficit exceeds the fungus tolerance to drought (RYDLOVÁ; PÜSCHEL, 2020). Thus, the guarantee of water to AMF species that are not tolerant to water deficit should favor their development.

The increase in mycorrhization in response to hydrogel doses also reveals that the evaluated polymer did not release harmful substances to fungi in the soil and did not favor microorganisms harmful to AMF. Rydlová and Püschel (2020) found that the polyacrylamide-based hydrogel applied to the soil reduced AMF colonization because the polymer favored the development of microorganisms antagonistic to mycorrhizal fungi.

The hydrogel was favorable to mycorrhization by increasing water availability in the soil, but it may have not reflected in the development of E. contortisiliquum. It occurs because information on the influence of water deficit on AMF is not very clear since the effects of lack of water on the establishment of symbiosis depend on the plant and the fungus species (AUGÉ et al., 2015).

\section{Soil nutrient contents}

The reduction in the soil Ca content with hydrogel doses in the treatment without mulch can be explained by the bond between the chemical element and the polymer. Polyvalent cations, especially divalent such as Ca, can bind to the hydrogel, displacing and replacing water molecules at polarized sites (SAHA et al., 2020). It impacts the polymer, as its ability to absorb water is reduced, but it also affects the soil from which Ca is taken.

In the case of increased Ca contents in the soil, observed from the hydrogel dose of $5 \mathrm{~g} \mathrm{~L}^{-1}$ in the treatment with mulch, even if the chemical element has changed with water, starting to bind to the polymer, the bagana which contains $\mathrm{Ca}$ in its composition (Table 2) and a $\mathrm{C} / \mathrm{N}$ ratio favorable to mineralization - released this nutrient to the soil, increasing its contents. The increase in moisture provided by hydrogel doses from $5 \mathrm{~g} \mathrm{~L}^{-1}$ contributed to the higher $\mathrm{Ca}$ content in the soil because it stimulates the decomposition of the mulch biomass. Abdelhafez et al. (2018) observed higher decomposition of organic residues and mineralization of nutrients in the soil of a semiarid region in response to higher moisture, as the higher water availability stimulated microorganism growth and increased the organic residue decomposition rate.

The results found for $\mathrm{K}$, following the same trend observed for $\mathrm{Ca}$, are also explained by the binding of the element to the polarized sites of the polymer. The increase in potassium contents in the soil for the treatment with mulch $(+\mathrm{M})$ is related to the ease of removal of this nutrient from organic residues in the presence of water. In this context, the carnauba palm bagana used in this study has $9.4 \mathrm{~g} \mathrm{~kg}^{-1}$ of potassium (Table 2), a value three times higher than that found by Oliveira et al. (2018).

Additionally, the used hydrogel was based on potassium polyacrylate (PONTES FILHO et al., 2018), that is, the polymer has potassium in its constitution. Abiotic factors associated with the presence of the mulch, such as moisture and increased ion concentration, may have favored the polymer degradation and potassium release into the soil solution with the hydrogel application in the field (XIONG et al., 2018). Biotic factors associated with the presence of mulch, such as light organic matter, may have stimulated the presence of microorganisms in the soil to promote the degradation of the polymer and, consequently, the release of $\mathrm{K}$ from its composition into the soil solution (XIONG et al., 2018).

As observed for $\mathrm{Ca}$ and $\mathrm{K}, \mathrm{Zn}$ in the soil may also have bound to the hydrogel in the absence of carnauba palm bagana, which led to a reduction in micronutrient contents. However, the presence of bagana led to an increase 
in the $\mathrm{Zn}$ content in the soil, as the material applied as a mulch contains $13.4 \mathrm{mg} \mathrm{kg}^{-1}$ of $\mathrm{Zn}$ in its composition (Table 2).

\section{Nutrient contents in the plant material}

The higher mycorrhization observed with the application of carnauba palm bagana and doses of hydrogel was expected to favor phosphorus $(\mathrm{P})$ absorption by E. contortisiliquum, but its leaf contents showed no response to the treatments. The AMF in studies in which mycorrhization increased the leaf content of $\mathrm{P}$ in plants came from native rhizosphere isolates of the host species (MANAUT et al., 2015; ABREU et al., 2018). However, the inoculation with exotic AMF (Gigaspora margarita) increased the leaf content of $\mathrm{P}$ of E. contortisiliquum (ABREU et al., 2018).

A low P availability in the soil favors mycorrhization, but AMF do not always benefit the nutrition and plant growth (NOGUEIRA; CARDOSO, 2007). It occurs because P compartments in the soil and the occurrence of factors limiting plant development, such as low water and nitrogen availability, are even more decisive in the contribution of AMF to the $\mathrm{P}$ absorption by plants.

Leaf calcium $(\mathrm{Ca})$ and magnesium $(\mathrm{Mg})$ contents responded to treatments. Moreover, higher Ca contents were observed in the absence of mulch $(-\mathrm{M})$, and its contents in the soil also responded to the treatments. However, it does not mean that mulch application reduced the Ca contents in the soil and plant material. As previously discussed, bagana contains $\mathrm{Ca}$ in its composition (Table 2) and released this nutrient into the soil to the point of increasing its contents due to the increasing hydrogel doses. Thus, the lower leaf Ca content in the treatment with bagana may be the result of a dilution effect related to higher plant growth. Dilution effect was observed in a tree species that produced more structural components (cellulose, lignin, cutin, and waxes), and low macronutrient contents did not represent nutritional deficiency (BUSSOTTI et al., 2000).

\section{CONCLUSIONS}

- The application of carnauba palm bagana resulted in a higher arbuscular mycorrhizal colonization in $E$. contortisiliquum than the hydrogel application, but without reflections on the leaf $\mathrm{P}$ content of the host species.

- Hydrogel application at a dose higher than $5 \mathrm{~g} \mathrm{~L}^{-1}$ associated with the addition of $10 \mathrm{Mg} \mathrm{ha} \mathrm{g}^{-1}$ of carnauba palm bagana increased $\mathrm{Ca}, \mathrm{K}$, and $\mathrm{Zn}$ contents in the soil. This is an interesting strategy for the revegetation of disturbed areas of the semiarid region. However, the leaf contents of these elements did not respond to the associated use of the polymer and mulch, possibly due to a dilution effect that requires further investigation.

- The evaluation of other characteristics of arbuscular mycorrhizal fungi, as well as measures of growth and accumulation of nutrients in the plant species, should be part of future studies to better understand the effects of hydrogel and carnauba palm bagana on the mycorrhization and development of E. contortisiliquum.

\section{ACKNOWLEDGMENTS}

To Coordination for the Improvement of Higher Level Personnel (CAPES), for granting a scholarship to graduate students involved in the research.

To Coordination for the Improvement of Higher Level Personnel (CAPES), for granting resources for research (Pró-Integração N0o 55/2013).

To Confederation of Agriculture and Livestock of Brazil (CNA) and Brazilian Agricultural Research Corporation (Embrapa), for granting funds for setting up the field experiment through the Biomas Project.

To Brazilian National Council for Scientific and Technological Development (CNPq), for granting a research productivity scholarship to the first author.

\section{REFERENCES}

ABDELHAFEZ, A. A.; ABBAS, M. H. H.; ATTIA, T. M. S.; BABLY, W. EL; MAHROUS, S. E. Mineralization of organic carbon and nitrogen in semi-arid soils under organic and inorganic fertilization. Environmental Technology \& Innovation, v. 9, p. 243-253, 2018. Diponsível em: https://doi.org/10.1016/j.eti.2017.12.011. Acesso em 01 jun. 2021.

ABREU, G. M.; SCHIAVO, J. A.; ABREU, P. M.; BOBADILHA, G. S.; ROSSET, J. S. Crescimento inicial e absorção de fósforo e nitrogênio de Enterolobium contortisiliquum inoculada com fungos micorrízicos arbusculares. Revista de Ciências Agrárias, v. 41, n. 1, p. 156-164, 2018. Disponível em: http://dx.doi.org/10.19084/RCA17138. Acesso em 01 jun. 2021.

AUGÉ, R.M.; TOLER, H.D.; SAXTON, A.M. Arbuscular mycorrhizal symbiosis alters stomatal conductance of host plants more under drought than under amply watered conditions: a meta-analysis. Mycorrhizan, v. 25, p.13-24, 2015. Disponível em: http://dx.doi.org/10.1007/s00572-014-0585-4. Acesso em 01 jun. 2021.

BUSSOTTI, F.; BORGHINI, F.; LEONZIO, C. C.C.; BRUSCHI, P. Leaf morphology and macronutrients in broadleaved trees in central Italy. Trees, v. 14, p. 361-368, 2000. Disponível em: http://dx.doi.org/10.1007/s004680000056. Acesso em 01 jun. 2021.

GONÇALVES, M. P. M.; FELICIANO, A. L. P.; MARANGON, L. C.; PAUlA SILVA, A.; SILVA, L. B.; LIMA NETO, E. M.; GRUGIKI, M. A. Potential of Artificial Bird Perches for Recovery Different Areas in Brazilian Semiarid. Journal of Experimental Agriculture International, v. 36, n. 1, p. 1-10, 2019 . Disponível em: http://dx.doi.org/10.9734/JEAI/2019/v36130228. Acesso em 01 jun. 2021. 
HODGE, A.; FITTER, A. H. Substantial nitrogen acquisition by arbuscular mycorrhizal fungi from organic material has implications for N cycling. Proceedings of the National Academy of Sciences, v. 107, n. 31, p. 13754-13759, 2010. Disponível em: http://www.pnas.org/cgi/doi/10.1073/pnas.1005874107. Acesso em 01 jun. 2021.

IPECE. Instituto de Pesquisa e Estratégia Econômica do Ceará. Perfil Básico Municipal 2017, Ibaratema. Fortaleza-CE, 2017, $18 \mathrm{p}$.

KOLAWOLE, G. O. Effects of leguminous plant residuesand NPK fertilizer application on the performance of yam (Dioscor ea rotunda 'cv' ewuru) in south western Nigeria. Archieves of Agronomy and Soil Science, v. 59, n. 3, p.1-12, 2012. Disponível em: http://dx.doi.org//10.1080/03650340.2011.638289. Acesso em 01 jun. 2021.

KOSKE, R. E.; GEMMA J. N. A modified procedure for staining roots to detect VA mycorrhizas. Mycological Research, v. 92, p. 486-505, 1989. Disponível em: http://dx.doi.org/10.1016/S09537562(89)80195-9. Acesso em 01 jun. 2021.

LORENZI, H. Árvores brasileiras: manual de identificação e cultivo de plantas arbóreas nativas do Brasil. Nova Odessa: Instituto Plantarum, 2009. v. 2, 3ed. 384p.

MANAUT, N.; SANGUIN, H.; OUAHMANE, L.; BRESSAN, M.; THIOULOUSE, J.; BAUDOIN, E.; GALIANA, A.; HAFIDI, M.; PRIN, Y.; DUPPONNOIS, R. Potentialities of ecological engineering strategy based on native arbuscular mycorrhizal community for improving afforestation programs with carob trees in degraded environments. Ecological Engineering, v. 79, p. 113-119, 2015. Disponível em: http://dx.doi.org/10.1016/j.ecoleng.2015.03.007. Acesso em 01 jun. 2021.

McGONIGLE, T. P., MILlER, M. H., EVANS, D. G., FAIRCHILD, G. L., SWAN, J. A. A new method which gives an objective measure of colonization of roots by vesicular -arbuscular mycorrhizal fungi. New Phytologist, v.115, n. 3, p. 495501, 1990. Disponível em: http://dx.doi.org/10.1111/j.1469-8137.1990.tb00476.x. Acesso em 01 jun. 2021.

NOGUEIRA, M. A.; CARDOSO, E. J. B. Phosphorus availability changes the internal and external endomycorrhizal colonization and affects symbiotic effectiveness. Scientia Agrícola, Piracicaba, v. 64, n. 3, p.295-300, 2007

OKON, I. E.; SOLOMON, M. G.; OSONUBI, O. The effects of arbuscular mycorrhizal fungal inoculation and mulch of constrasting chemical composition on the yield of cassava under humid tropical conditions. The Scientific World Journal, v. 10, p. 505-511, 2010.

OLIVEIRA, L. S.; COSTA, M. C. G.; SOUZA, H. A.; BLUM, J.; ALBUQUERQUE, G. H. S.; ABREU, M. G. P.; MAIA, D. S. Characterization of organic wastes and effects of their application on the soil. Journal of Agricultural Science, v. 10, p. 291-298, 2018. Disponível em: http://dx.doi.org/10.5539/jas.v10n6p291. Acesso em 01 jun. 2021.

PAGANO, M. C.; UTIDA, M. K.; GOMES, E. A.; MARRIEL, I. E.; CABELLO, M. N.; SCOTTI, M. R. Plant-type dependent changes in arbuscular mycorrhizal communities as soil quality indicator in semi-arid Brazil. Ecological Indicators, v. 11, n. 2, p. 643-650, 2011. Disponível em: http://dx.doi.org/10.1016/j.ecolind.2010.09.001. Acesso em 01 jun. 2021.

PONTES FILHO, R. A.; GONDIM, F. A.; COSTA, M. C. G. Seedling growth of tree species under doses of hydrogel and two levels of luminosity. Revista Árvore, v. 42, n. 1, p.1-9, 2018. Disponível em: http://dx.doi.org/10.1590/180690882018000100012. Acesso em 01 jun. 2021.

POSADA, R. H.; FRANCO, L. A.; RAMOS, C.; PLAZAS, L. S.; SUÁREZ, J. C.; ALVAREZ, F. Effect of physical, chemical and environmental characteristics on arbuscular mycorrhizal fungi in Brachiaria decumbens (Stapf) pastures. Journal of Applied Microbiology, v. 104, n.1 p. 132-140, 2008. Disponível em: http://dx.doi.org/10.1111/j.1365-2672.2007.03533.x. Acesso em 01 jun. 2021.

POWELL, J. R.; RILLIG, M. C. Biodiversity of arbuscular mycorrhizal fungi and ecosystem function. New Phytologist, v. 220, p. 1059-1075, 2018. Disponível em: http://dx.doi.org/10.1111/nph.15119. Acesso em 01 jun. 2021.

RODORFF, V.; STEINMETZ, L.; MERTENS, J.; SIEGMUND-SCHULTZE, M.; KÖPPEL, J. Applying Bayesian networks to evaluate small-scale farmers' perceptions of native reforestation practices in Brazil's Caatinga biome. Regional Environmental Change, v. 18, p. 1983-1997, 2018. Disponível em: http://dx.doi.org/10.1007/s10113-018-1370-2. Acesso em 01 jun. 2021.

RYDLOVÁ, J.; PÜSCHEL, D. Arbuscular mycorrhiza, but not hydrogel, alleviates drought stress of ornamental plants in peatbased substrate. Applied Soil Ecology, v. 146, 2020. Disponível em: https://doi.org/10.1016/j.apsoil.2019.103394. Acesso em $\underline{01 \text { jun. } 2021 .}$

SAHA, A.; SEKHARAN, S.; MANNA, U. Superabsorbent hydrogel (SAH) as a soil amendment for drought management: A review. Soil \& Tillage Research, v. 204. 2020. Disponível em: http://doi.org/10.1016/j.still.2020.104736. Acesso em 01 jun. 2021.

SOBRAL, L. F.; BARRETOO, M. C. V.; SILVA, A. J.; ANJOS, J. L. Guia prático para interpretação de resultados de análise de solo. Aracaju: Embrapa Tabuleiros Costeiros, 2015. 13p.

TEIXEIRA, P. C; DONAGEMMA, G. K.; FOnTANA, A.; TEIXEIRA, W. G. Manual de métodos de análise de solo. Brasília: Embrapa Informação Tecnológica, 2017. 3.ed., rev. e ampl. 573p.

XIONG, B.; LOSS, R. D.; SHIELDS, D.; PAWLIK, T.; HOCHREITER, R.; ZYDNEY, A. L.; KUMAR, M. Polyacrylamide degradation and its implications in environmental systems. Clean Water, v.1, p.1-17, 2018. Disponível em: http://doi.org/10.1038/s41545-018-0016-8. Acesso em 01 jun. 2021.

FLORESTA, Curitiba, PR, v. 51, n. 3, p. 741-750, jul/set 2021. 